\title{
The Baskerville punches: revelations of craftsmanship
}

Caroline Archer-Parré, Ann-Marie Carey, Keith Adcock

Centre for Printing History \& Culture, Birmingham City University

Birmingham City University, Centre for Printing History \& Culture, The Parkside Building, 5 Cardigan Street, Birmingham B4 7RJ

caroline.archer@bcu.ac.uk

@typetweets. @printhistory

\section{Biographical details}

Caroline Archer-Parré is Professor of Typography, Co-director of the Centre for Printing History and Culture at Birmingham City University, and Chairman of the Baskerville Society. With a particular interest in printing and typographic history of the English Midlands from the eighteenth to twentieth centuries, she has published widely and is the author of three books, a contributing author to numerous journals, and a regular contributor to the trade and academic press.

Ann-Marie Carey is an Associate Professor in the School of Jewellery, Birmingham City University. She specialises in combining craftsmanship with laser technology to introduce new perspectives of understanding. She has worked with museums in London and Birmingham to create replicas of the Cheapside Hoard and Staffordshire Hoard respectively. Carey combines the traditional craftsmanship skills of goldsmithing with advances in laser technology to present new perspectives of understanding, and novel approaches to the development of the craft.

Keith Adcock is a senior CAD CAM technologist at the Centre for Digital Design and Manufacturing with over forty years' experience in the jewellery industry. Adcock's career has bridged both the physical and virtual construction of objects, initially apprenticed to the trade, he specialised in dies and tools for manufacturing jewellers. He subsequently interfaced the physical knowledge of 
tool manufacture with CAD CAM and downstream activities such as rapid prototyping, laser scanning and sintering.

\begin{abstract}
Eighteenth-century punch-cutting was not only difficult to execute, it was also difficult to document, therefore, knowledge of early typographic practices is generally limited. Fortunately, the punches of one of the century's foremost English printers, John Baskerville (1707-75), still survive as the primary evidence of craftsmanship and the punch-cutters skill and the means of their manufacture. This article looks at what is known and, more importantly, what is not known about the processes, materials and techniques employed in the manufacture of Baskerville's punches. It presents a pilot project designed to explore new methodological approaches to describing and analysing this important typographical material. It also suggests how the methodology can be applied in order to enhance our understanding of Baskerville beyond his books.
\end{abstract}

\title{
Keywords
}

3-D printing, Baskerville, bibliography, Birmingham, Cambridge University Press, Cambridge University Library, laser scanning, metal, punch-cutting, Reflectance Transformation Imaging, X-Ray Fluorescence 


\section{The Baskerville Punches: revelations of craftsmanship}

Caroline Archer-Parré, Ann-Marie Carey, Keith Adcock

'Baskerville', with its well-considered design and elegant proportions its 'methods of thickening or thinning parts of a letter, and its sharp and horizontal treatment of serifs', is one of the world's most widely used, enduring and influential typefaces. ${ }^{1}$ It was created in Birmingham by John Baskerville (170775), printer and entrepreneur, an Enlightenment figure with a worldwide reputation who changed the course of type design. ${ }^{2}$ Baskerville is known as the 'complete printer' because he considered all aspects of the craft by experimenting with casting and setting type, improving the construction of the printing press, developing a new kind of paper and refining the quality of inks. His typographic experiments put him ahead of his time, had an international impact and did much to enhance the printing and publishing industries of his day. The volumes he created in Birmingham-from an edition of Virgil's poetry (1757) to his final publication, William Hunter's magisterial The anatomy of the human gravid uterus (1774) - are recognised by printing historians, librarians and bibliophiles as masterpieces of the art and craft of book making which, as T.B. Macaulay wrote, 'went forth to astonish all the librarians of Europe'. ${ }^{3}$ In 1758 Baskerville sought, and secured, a patent to become printer to the University of Cambridge, a post he held until 1766. While in Cambridge he printed four editions of the Book of Common Prayer (1760) and a folio Bible (1763) which is still regarded as one of the world's most beautifully printed books.

Current understanding of the life and work of Baskerville comes from earlier scholars who collectively provide excellent biographical and bibliographical approaches to the printer. ${ }^{4}$ His inclusion in the Oxford Dictionary

\footnotetext{
1 J. Deyfus, 'The Baskerville Punches 1750-1950' in Into Print: selected writings on printing history, typography and book production. (London: The British Library, 1994).

2 J. Mosley, 'Baskerville, John (1706-75)', Oxford Dictionary of National Biography $<$ http://0www.oxforddnb.com.catalogue.wellcomelibrary.org/view/article/1624> [accessed 14 Nov 2015]. 3 T. B. Macaulay, The history of England, Volume 2. (London: Penguin Classics, 1979).

${ }^{4}$ W. Bennett, John Baskerville: the Birmingham printer (Birmingham: City of Birmingham School of Printing, 1937); J. H. Benton, John Baskerville: typefounder and printer, 1706-75 (Boston: Privately Printed, 1914); H. H. Bockwitz, Baskerville in the judgement of German contemporaries (Birmingham: City of Birmingham School of Printing, 1937); T. Cave, John Baskerville: the printer 1706-75, his ancestry (Birmingham: City of Birmingham School of Printing, 1936); F. E. Pardoe, John Baskerville of Birmingham, letter-founder and printer (London: Frederick Muller, 1975); R. Straus and R. Dent, John Baskerville: a memoir (London: Chatto \& Windus, 1907).
} 
of National Biography demonstrates the importance of the man and recognises the international authority of his typeface. ${ }^{5}$ John Baskerville: art and industry of the Enlightenment, edited by Caroline Archer-Parré and Malcolm Dick, provides the most up-to-date and wide-ranging picture of Baskerville and his impact.6 Yet despite his significance and influence much of Baskerville's work remains unexplored. In their 'Introduction' Archer-Parré and Dick suggest new avenues for Baskerville scholarship, including a review of the physical and material aspects of his manufacturing process. This article takes up this suggestion. Firstly, it looks at what is known and, more importantly, what is not known about the processes, materials and techniques employed in just one area of Baskerville's manufacture: punch-cutting. Secondly, it presents a pilot project designed to explore new methodological approaches to describing and analysing this important typographical material. The article concludes with some suggestions as to how the methodology can be applied in order to enhance our understanding of Baskerville beyond his books.

\section{Baskerville the 'complete printer'}

John Baskerville was born in Wolverley, Worcestershire, in 1707. He arrived in Birmingham in about 1726, 'having trained in no occupation' and established a school in the Bull Ring from where he taught handwriting.7 By 1736 he was also carving letters for headstones. ${ }^{8}$ In 1740 he began manufacturing japanwarefashionable household products made from decorated and lacquered tin-a trade from which he amassed a fortune. ${ }^{9}$ It was Baskerville's substantial wealth that enabled him in 1750, aged forty-three, to return to his first love, letters. But, on this occasion he chose to combine his understanding of letterforms with the great technological invention of his day, printing.

\footnotetext{
5 H. R. Tedder, 'John Baskerville' Oxford Dictionary of National Biography Vol 3 (Oxford 1885); J. Mosley, 'Baskerville, John (1706-75)', Oxford Dictionary of National Biography (Oxford, 2004). ${ }^{6}$ C. Archer-Parré, M. Dick, eds., John Baskerville: art, industry and technology in the Enlightenment (Liverpool: Liverpool University Press, 2017).

7 W. Hutton, 'An account of John Baskerville, printer', The Edinburgh Magazine or literary miscellany (1785), 375. G.Demidowicz, 'Place, Home and Workplace: Baskerville's birthplace and buildings' in John Baskerville: art and industry of the Enlightenment, ed. by C. Archer-Parré and M. Dick (Liverpool: Liverpool University Press, 2017), pp. 42-70.

${ }^{8}$ Straus \& Dent, p. 4.

9 Y. Jones, 'Japanner of "Tea Trays and other Household Goods"', in John Baskerville: art and industry of the Enlightenment, ed. by C. Archer-Parré and M. Dick (Liverpool: Liverpool University Press, 2017), pp. 71-86; Y. Jones, Japanned Papier Mâché and Tinware c.1740-1940 (Woodbridge: Antique Collectors Club Limited, 2012), pp. 115-18.
} 
That Baskerville, with neither training nor experience, should engage with the craft of printing was unusual. It was, after all, only a few short years since state control over printing in England was lifted in 1695-control that had ensured no press was erected outside London, except in the university towns of Oxford and Cambridge and the city of York. These restrictions not only regulated the number of presses and printers, but also determined what could, and could not, be produced. ${ }^{10}$ In addition, no one was able set up as a master printer without serving a seven-year apprenticeship. Master printers defended their privileges and protected their skills, ${ }^{11}$ to ensure that only they could issue printed material.12 Just as parliament had imposed restrictions on the printing trade, so the trade itself enforced tight controls on who could join it and how it operated. Printing was, therefore, almost impenetrable to outsiders, such as Baskerville, who wished to engage with the craft.13

How Baskerville became interested in printing is unknown. There was little practical reading matter for the eighteenth-century amateur printer, but it is possible that Baskerville read the twenty-page pamphlet, 'Some observations on the use and origin of the noble art and mystery of printing', written and printed by Francis Burges in 1701.14 This little publication, one of the earliest published accounts of the subject in English, demonstrates the current state of knowledge of printing history at the time. Alternatively, the more widely available, but anonymous, article: 'An essay on the original use and excellency of the noble art and mystery of printing', which appeared in the London Weekly Register, 9 September 1732, could also have aroused Baskerville's interest in the typographer's craft. For guidance on contemporary practices in typefounding, composition and presswork Baskerville may have accessed Joseph Moxon's Mechanick exercises on the whole art of printing (1683). ${ }^{15}$ Moxon's extensive

10 Star Chamber Decree (1637); 'Act for preventing abuses in printing seditious, treasonable and unlicensed books and pamphlets, printing and printing presses' (1662). R. Astbury, 'The renewal of the licensing act in 1693 and its lapse in 1695', The Library xxxiii, iv, (Oxford: Oxford University Press, December 1978), pp. 298-322.

11 D. Jury, Graphic Design before graphic designers: the printer as designer and craftsman, 17001914. (London: Thames \& Hudson, 2012), pp. 15-16.

12 T. A. Skingsley, 'Technical training and education in the English printing industry', Printing Historical Society Journal (1978/9), xiii, 1-25.

${ }^{13} \mathrm{C}$. Archer-Parre, 'Private pleasures and portable presses: do-it-yourself printers in the eighteenth-century', in Text, type and communication in the eighteenth century (Liverpool: Liverpool University Press, 2020).

14 J. Dreyfus, 'Baskerville's method of printing,' in Signature, vol. 12, New Series (1951), pp. 44-49; A copy of the publication can be found in the British Library, General Reference Collection, 185.a.7, UNI BLL01000535308, The Harleian Miscellany, etc. London, 1744-46, vol. 3 (1745).

${ }^{15}$ J. Moxon, Mechanick Exercises, or the Doctrine of Handy-works Applied to the Art of Printing (London: 1683). 
publication was an instruction manual detailing the techniques used by seventeenth-century printers and would have provided Baskerville with the necessary information for establishing his own printing house. However, the excessive detail provided by Moxon on the one hand, coupled with omissions and inaccuracies on the other, may have rendered it of limited practical assistance to a novice if used on its own. Baskerville's wealth certainly enabled him to purchase the services of local craftsmen-John Handy was his punchcutter and Robert Martin his pressman-to assist with his typographic undertakings. ${ }^{16}$ He probably also employed other workers. ${ }^{17}$ Birmingham's trades of metal engraving meant there was a steady supply of proficient artisans whose skills transferred easily to the printing trade. From this body of craftsmen Baskerville could have easily recruited the labour which ensured the punches and matrices necessary for the development of his type were made to the exacting standards he required..$^{18}$ But Baskerville was not simply a bystander in his printing workshop, he laboured alongside those he employed and actively participated in all aspects of the craft including designing type, cutting punches, printing and binding. ${ }^{19}$ Exactly how Baskerville furnished himself with the skills of the trade is, therefore, open to speculation but it was probably a combination of inspiration from contemporary printing manuals alongside guidance from those he employed, coupled with an aptitude for mechanical processes and a natural curiosity.

Eighteenth-century type-making was a singular process and there is no reason to suppose that Baskerville approached the design, production and reproduction of his typeface differently from that of his contemporaries. Initially Baskerville drew the design for his typeface on paper in two-dimensional form. ${ }^{20}$ Translating his two-dimensional designs into three-dimensional type was a three-stage process. The first stage, punch-cutting, was done by taking short lengths of steel on which his letters were cut in reverse and in relief at one end. An exceptionally high level of metalworking and engraving skills was required in order to cut the punches and accurately reproduce Baskerville's design. The

16 T. B. Reed, $A$ history of the old English letter foundries, (London: Faber \& Faber, 1952), pp. 26788.

17 Pardoe, pp. 23-46.

18 Dreyfus, Signature, pp. 44-9.

19 Birmingham Archives \& Collections, Library of Birmingham (BA\&C), MS 1385, 'Baskerville letter to R. Dodsley 2 October 1752'.

20 M. Audin, 'Claude Jacob' in Histoire de l'imprimerie par l'image, (Paris: H. Jonquieres, 1929). 
punch would have been subject to 'tempering', a process of heat treating, which increased the toughness and reduced the brittleness of the punch and enable its use as a tool. After tempering, the punch was then placed against a softer piece of metal, such as copper. The punch was hit with a hammer, driving it into the surface of the softer metal and leaving an impression of the 'right-reading' character to be cast. This is called the matrix. Baskerville's type was manufactured when the matrix was passed to the type-caster who inserted it into a mould. The type-caster then took a ladle of molten type metal-an amalgam of tin, antimony and lead-and poured it into the funnel in the top of his mould. This produced a cast of the type in relief and in reverse. The typecaster could make as many copies of Baskerville's type as needed. It was then distributed into wooden cases ready for the compositor to set the text required for Baskerville's books. When the type was printed on the page it was, of course, 'right-reading' and two-dimensional.21 (FIGURE 1)

Punch-cutting was the most complexed and skilled of all the typographic processes. It was also the most restricted. Punch-cutting was often treated as a trade secret and sometimes, as in the case of William Caslon the Elder (16921766), passed from father to son or master to apprentice behind closed doors and away from prying eyes. ${ }^{22}$ As Moxon wrote, 'Letter-Cutting is a Handy-Work hitherto kept so conceal'd among the Artificers of it, that I cannot learn anyone hath taught it any other; ... Therefore, I cannot (as in other Trades) describe the general practice of the Work-Man.'23 Punch-cutting was not only difficult to execute, it was also difficult to document. Therefore, our knowledge of early punch-cutting practices in general, and our understanding of Baskerville's punch-cutting habits in particular, is limited. In the absence of Baskerville's workshop manual, the punches are the primary evidence of his craftsmanship, silent witnesses to the punch-cutters' skill.

\section{The survival of Baskerville's punches ${ }^{24}$}

\footnotetext{
21 E. Howe, 'The typecasters', Monotype Recorder (1957); N. Gable, A. Boucel, Drawing the movement: cutting the type punch (Paris: Editions des Cendres, 2019); J. Moxon, Mechanick Exercises, or the Doctrine of Handy-works Applied to the Art of Printing (London: 1683); P-S. Fournier, Manuel Typographique (Paris, 1764).

22 J. Mosley, 'William Calson the Elder', Oxford Dictionary of National Biography <oxforddnb.com/view/article/4857> [accessed 20 February 2020].

${ }^{23}$ Moxon p. 87.

24 J. Dreyfus, The survival of Baskerville's punches (Cambridge: Privately Printed, 1949).
} 
While there are many eighteenth-century printed books in libraries and personal collections around the world, little of the material that made them has survived. Fortunately, in addition to Baskerville's books, his punches have also endured, though their survival is as much by chance as by design.

When Baskerville died in 1775 his apparatus for type-founding was sold by his widow, Sarah, to Pierre-Augustin Caron de Beaumarchais (1732-99) for $£ 3,700$. Beaumarchais regarded Baskerville’s type as the most beautiful printing types known and used them in the production of his Kehl editions of Voltaire's works. ${ }^{25}$ Subsequently Beaumarchais took the punches to Paris where they remained until 1953. In the course of a century-and-a-half the punches changed hands four times and their origin was forgotten. In 1818 Beaumarchais's daughter sold the Baskerville material, inherited from her father, to Pierre Didot the elder (1761-1853), who passed them to his son, Jules Didot (1794-1871). In 1842 the punches were handed to the brothers Plon, whose firm later became E. Plon, Nourrit et Cie. In 1893, Plon sold the unrecognised Baskerville punches to Fonderie Bertrand, who cast Baskerville's founts under the name of Elzevirs ancient and advertised them in its 1917 prospectus. It was the American typographer, Bruce Rogers (1870-1957) who, having seen the prospectus, first suspected their true identity. In November 1936, Fonderie Bertrand was bought by Fonderies Deberny et Peignot, who acquired Baskerville's punches along with his matrices. Its director, Charles Peginot (1897-1983), generously offered to return them to Britain and presented them to the University of Cambridge on 12 March 1953, after they had spent nearly 180 years in France. ${ }^{26}$

The event was of considerable moment to all those interested in typography and their return was reported in both the national and local press. ${ }^{27}$ The ceremony took place in the gallery of Emmanuel College, Cambridge where, in the presence of the French Ambassador, René Massigili (1888-1988), the Vice-Chancellor, Sir Lionel Whitby (1895-1956), received on behalf of the University the original Baskerville punches from Charles Peignot. Sir Lionel

\footnotetext{
25 J. Dreyfus, 'The Baskerville Punches', Into Print, (London: British Library, 1994), pp. 13-36. 26 'John Baskerville's Punches, Printing Review, no. 62, (1964), 17-18; J. Dreyfus, The survival of Baskerville's punches (Cambridge: Privately Printed, 1949); J. Dreyfus, 'The Baskerville Punches 1750-1950', Library, ser. 5, vol., 5., (1951) 26-48; R. Flower, 'The Fate of the Baskerville Types', Library, ser. 2, vol., 10, (1909) 251-2.

27 'Frenchman's gift to Cambridge Press: Baskerville type punches', The Times, 16 February 1953; 'Baskerville type' The Times, 2 March 1953; 'Baskerville punches' The Times, 6 March 1953; 'Made in Birmingham', Birmingham Mail, 7 March 1953; 'Baskerville and Baldwin', Birmingham Mail, 12 March 1953; 'Gift to Cambridge University: eighteenth-century matrices of Birmingham Printer', Birmingham Post, 13 March 1953; 'Return to Cambridge of Baskerville punches: M. Peignot's gift', The Times, 13 March 1959.
} 
expressed the gratitude of the University and declared that the return of the punches was not only a tribute to the University Press but also a gesture of the larger significance of Anglo-French co-operation in the sphere of learning and culture. Guests included Sydney Castle Roberts (1887-1966), Master of Pembroke and former Secretary to Cambridge University Press (CUP); Edward Welbourne (1894-1966), the historian and Master of Emmanuel, H. S. Bennett (1889-1972), Fellow of the British Academy and Chairman of the Syndics of the Press; Stanley Morison (1889-1967), the typographer and printing historian ; R. J. L. Kingsford (1900-78) author and secretary of the University Press; and Brooke Crutchley (1907-2003) the then University Printer. ${ }^{28}$

That Baskerville's punches should be donated to Cambridge rather than Birmingham is, perhaps, curious. Peignot was convinced of the suitability of returning the punches to what he called their 'ancestral home' and The Times declared the gift 'as appropriate as it is generous'. ${ }^{29}$ Baskerville's Cambridge Bible is undoubtedly a masterpiece of printing; however, the punches with which it was created were made by Baskerville in Birmingham where he was assisted by skilled Midlands craftsmen. While the Syndics of the University Press had, in 1758, unanimously elected Baskerville to be its printer for the term of ten years, the relationship was not a happy one. Baskerville complained that he worked 'under such shackles as greatly hurt him' and the enterprise cost him dearly. ${ }^{30}$ It may be hoped that Baskerville, as The Times suggested, would have felt 'the University had made amends' by accepting and archiving his punches.

\section{The Cambridge collection of Baskerville punches (FIGURE 2)}

The Baskerville punches are currently owned by CUP, 31 and housed in the Historical Printing Room at the University Library, Cambridge (ULC) where they are carefully cared for alongside other historic typographic material. ${ }^{32}$ The punches are arranged according to size and stored in wooden boxes which, while beautifully crafted, are not contemporaneous to the punches but were made later, perhaps, by one of the Parisian type-foundries. Reports and records

\footnotetext{
28 'Return to Cambridge of Baskerville punches: M. Peignot's gift', The Times, 13 March 1959.

29 'Gift to Cambridge University: eighteenth-century matrices of Birmingham Printer', Birmingham Post, 13 March 1953.

30 'Baskerville letter to Walpole, 2 November 1762' Letters of John Baskerville, L. Jay ed., (Birmingham: City of Birmingham School of Printing, 1932).

31 Cambridge University Press, <htttp://cambridge.org> [accessed 11 January 2020].

${ }^{32}$ Historical Printing Room, <http://lib.cam.ac.uk/collections/departments/rare-books/rarebooks-collections/historical-printing-room> [Accessed 11 January 2020].
} 
made at the time of deposit suggest the collection comprised around 2,750 extant Baskerville punches. ${ }^{33}$ The punches, however, do not consist exclusively of material made by Baskerville in eighteenth-century Birmingham. In 1950 the printing historian John Dreyfus (1918-2002) compared the punches of the Greek type made by Baskerville for Oxford University Press ${ }^{34}$ with the punches bought by Deberny et Peignot and concluded that 'approximately three-quarters of the punches were made under the same supervision as those at Oxford'. ${ }^{35}$ Of the remainder some are eighteenth-century French-made replacements for those originals which were either damaged and discarded or were lost. Other punches are eighteenth-century additions made to provide the diacritical marks required for the printing of Beaumarchais's Kehl edition of Voltaire. Others are twentieth-century French-made supplements. The collection includes punches for both roman and italic and upper and lower-case characters, with figures and punctuation marks in seventeen sizes:

$\begin{array}{ll}\text { Old English type size } & \text { point size } \\ \text { Nonpareil } & 6 \\ \text { Minion } & 7 \\ \text { Brevier } & 8 \\ \text { Burgeois } & 9 \\ \text { Long Primer } & 10 \\ \text { Small Pica } & 11 \\ \text { Pica } & 12 \\ \text { English } & 14 \\ \text { 2-line Brevier } & 16 \\ \text { Great Primer } & 18 \\ \text { Paragon } & 20 \\ \text { Double Pica } & 24 \\ \text { 2-line English } & 28 \\ \text { 2-line Great Primer } & 36 \\ \text { 2-line Double Pica } & 40 \\ \text { French Canon } & 48\end{array}$

33 P. Gaskell, John Baskerville: a bibliography, (Cambridge: Cambridge University Press, 1959). 34 G. Leonidas, 'A reappraisal of Baskerville's Greek types', in John Baskerville: art and industry in the Enlightenment (Archer-Parré \& Dick eds), (Liverpool: Liverpool University Press, 2017), pp. 133-51.

35 Dreyfus, Into print, pp. 13-36. 
Of the above, Baskerville does not appear to have produced punches for either Minion (7pt) nor Paragon (20pt) as they are not included on any of his type specimens. Nor did Philip Gaskell (1926-2001), in his detailed bibliography of Baskerville's works, identify their use in any of the printer's publications. ${ }^{36}$ These sizes may, therefore, be eighteenth-century French additions rather than Baskerville originals.

When the punches were donated to Cambridge in 1953 they were accompanied by 'check-out' sheets on which Deberny et Peignot had recorded, size-by-size, each individual punch which left their premises. ${ }^{37}$ On arrival in Cambridge the Library checked-in, on the same sheets, those punches which had been received. Everything that was checked-out was accounted for in Cambridge. However, there is a significant discrepancy between the number of punches that both Dreyfus and Gaskell estimated-2,750 - and the number that were deposited by Deberny et Peignot in Cambridge-2,599. This may be because Dreyfus simply over-estimated the number of punches he had seen, or it may be that some were lost, or perhaps removed, prior to despatching to Cambridge. Further doubts around the exact quantity arise because a selection of the punches was later returned to France. In March 1953 Charles Peignot wished to launch a new series of Baskerville types for which he needed to make fresh matrices. To do so he requested 380 of the punches given to Cambridgeboth roman and italic and in sizes from $6 \mathrm{pt}$ to $40 \mathrm{pt}$-be returned to Paris on loan for close study. Some of these punches were given back to Cambridge in 1960, but a letter from Charles Peignot to John Dreyfus, dated 27 June 1973, shows that some still remained in Paris: ${ }^{38}$

Dear John,

Here is some information that may interest you.

Adrian told me that he had found at Deberny and Peignot's some Baskerville punches that we had kept in order to finish the engravings that we had undertaken.

\footnotetext{
36 P. Gaskell, John Baskerville: a bibliography, (Cambridge, 1959).

37 University Library Cambridge (ULC), MS Add 9815/D, Box 64: John Baskerville, papers of John Dreyfus.

38 ULC, MS Add 9815/D Box 64.
} 
I admit, to my confusion, that I had completely forgotten about them.

However, today I received from Higonnet an inventory of punches which have remained with Deberny and Peignot and I note that we have:

Baskerville roman and italic: $6-10-12-14-16$

Baskerville italic: 8 - 9

And 6 italic punches

Adrian, who had a conversation on this subject with Higonnet, told him that these punches belonged to Cambridge and we should hand them over to the University. It's obvious they should be returned but we haven't spoken about it about it yet because I want to check for myself that these are not damaged punches. It would surprise me if they were, because Adrian would not be too proud on this point. 39

No further correspondence exists either confirming the condition of these punches or whether or not they were returned to Cambridge. If not in Cambridge, then where are they? It is a problem waiting to be solved.

A further question mark over the collection concerns the whereabouts of the Baskerville matrices. Dreyfus stated: 'In November 1936 the material of Bertrand's foundry was sold to Deberny et Peignot, to whom were transferred 2,750 punches and 3,052 matrices for the making of Baskerville type.' 40 There is no extant documentation evidencing the transfer of the matrices to the University: whether they still exist or whether they have been destroyed is not known and is still to be investigated.

\section{The pilot project}

Regardless of the uncertainties surrounding the collection, the Baskerville punches are significant and of much interest to the typographic historian as they provide a direct link back to Baskerville. Therefore, in 2019, thanks to the generosity of History West Midlands Ltd., a small pilot project was established to undertake preliminary investigations into the Baskerville punches. ${ }^{41}$ The project was a collaboration between the Centre for Printing History and Culture, Birmingham; ${ }^{42}$ the Centre for Digital Design and Manufacturing in the School of

\footnotetext{
${ }^{39}$ Author's translation from the original French.

40 J. Dreyfus, The Library, (1950), pp. 26-48.

${ }^{41}$ History West Midlands, < https://historywm.com > [Accessed 11 January 2020].

${ }^{42}$ Centre for Printing History and Culture, $<$ https://www.cphc.org.uk $>$ [Accessed 11 January 2020].
} 
Jewellery at Birmingham City University; 43 the Digital Content Unit, University of Cambridge; 44 and the Birmingham Assay Office. ${ }^{45}$ The partnership brought together experts from different institutions and disciplines each with their own methodological approaches. The participants comprised historians, technicians and makers working in the areas of craft, digital humanities, jewellery, metallurgy, material culture, printing and typography. Collectively they contributed both the theoretical and practical expertise which underpinned the development and assessment of an original methodology which had been designed to allow a detailed visual, physical and material analysis of the punches. In the course of undertaking this pilot project, our work in progress was filmed as a visual record of what was undertaken. The film was made by ICE Productions, Birmingham and is available to view online. 46

While Baskerville's typeface has captured the attention of printing historians, little consideration has been given to the material aspects of its manufacture. 47 This project was, in the first instance, interested in the 'face' of the punches, as it represents the height of craftsmanship and skill that were needed to achieve a master surface suitable for consistent reproduction. However, the 'face' was just the final, accumulative stage in its manufacture and there is a significant difference between the surfaces of the 'face', polished with all traces of tool marks removed, and those of the shank which are raw and functional. It is these raw surfaces that bear witness to the marks of manufacture that were of particular interest to the project. It was hoped that deciphering these marks would provide valuable clues to the skills, levels of technology and material understanding required for their production. The object of the pilot project was, therefore, firstly to develop a range of methodologies which could be used to examine the punches; secondly to test the methodologies on a small sample of the punches in order to determine their efficacy; thirdly to ascertain what data could be obtained using these methods; and finally, to consider the way forward.

43 Birmingham City University, School of Jewellery, < https://www.bcu.ac.uk/jewellery> [Accessed 11 January 2020].

44 University of Cambridge, Digital Content Unit, $<$ https://www.lib.cam.ac.uk/collections/departments/digital-content-unit $>$ [Accessed, 11 January 2020].

${ }^{45}$ Assay Office Birmingham, <https://theassayoffice.com> [Accessed, 11 January 2020].

46 The lasting legacy of Birmingham's Famous Printer, $<$ https://historywm.com/films/the-lastinglegacy-of-birminghams-famous-printer> [accessed 20 February 2020].

${ }_{47}$ B. Warde, 'The Baskerville Types: a critique', The Monotype Recorder, vol, 26., no. 221, (1927) pp. 3-27. 
Due to financial, time and practical constraints, it was not possible to examine all the punches. Instead it was decided to work with a single character in ten different sizes: the lower-case ' $g$ ' in sizes $14,16,18,20,24,28,36,40,48$ and 60pt. The lower-case ' $\mathrm{g}$ ' was chosen as it is one of Baskerville's 'spot characters', a particularly distinctive letter commonly used to help identify Baskerville from other typefaces. It is also a complex character with significant contrast between thick and thin strokes and multi-directional curves, the production of which would have presented particular challenges for the punchcutter. The ten largest sizes were selected in order to optimize the capabilities of the digital technologies deployed in the project, to increase the chances of capturing detailed images, and maximise the probability of producing useful data. The same ten punches were used throughout the pilot project so that different datasets from the same set of punches could be combined; this added credibility both to the project and the different skillsets involved. Working with the same set of punches also increased the possibility of producing novel findings both in terms of technical compatibility of the methodologies and historical insights into the punches. For example: to demonstrate a range of cutting techniques or to consider scale and magnification across a single character in multiple sizes.

\section{Methods 1-3: Reflectance Transformation Imaging; Laser Scanning; 3-D Printing}

In the first instance the Digital Content Unit at the University of Cambridge used high-resolution imaging for the digitisation of the ten punches. The technology, Reflectance Transformation Imaging (RTI), is an innovative specialist photographic method which uses multiple images of the same scene in order to create two-dimensional textured images of the punches and present otherwise invisible features on the surface. These were created from multiple digital photographs of each punch taken from a fixed camera position. Each photograph contained information on light projected from a different angle. The final mathematically rendered image presented the punches with varying highlights and shadows. The bulk of the digital output was saved in 8bit TIFF with Adobe 1998 colour profiles and an equivalent TEI P5 file containing description, licence information, structural data, and in some cases transcription. It was anticipated that the physical features revealed by the RTI could then be interpreted as evidence of manufacture. 
The RTI images were presented alongside traditional imaging produced by the Centre for Digital Design and Manufacture who used specialist laser scanning, computer-aided design (CAD) and three-dimensional printing facilities to create three-dimensional replicas of the punches. Data from the punches was collected via visual inspection, digital photography and laser scanning. In the first instance, a jewellers' loupe-a small-scale magnification glass-was used to 'scope' the punches and distinguish significant features. This analogue engagement with the punches was important because a significant part of the encounter was the direct hand and eye experience which allowed a visual and haptic appraisal of the objects, thus giving a direct sense of their purpose. In addition, the close inspection was necessary in order to identify points of registration for the laser scan. The punches were scanned while fixed in a custom jig. A number of laser scans were taken from different perspectives and the individual scans were registered to each other via three points of reference and digitally stitched together. The scans produced a three-dimensional point cloud of digital data-a digital skin of high- and low-points which represents the topology of the surface of the punches thereby accurately capturing the size, scale, surface and texture of each punch. The scan was the digital foundation upon which the CAD files were generated. These files captured the physical features of the punches and produced a digital document and accessible resource. Exported as a Seriolithography (STL) file, further physical downstream outputs were created, in particular three-dimensional polymer printed models of the punches. Taking up to ten hours to print each punch, the 3-D printer replicated most of the details and served to give a sense of scale, height, breadth and density in a format that could be handled. The 3-D printed punches turned the virtual into the tangible, thereby opening up the possibility of revealing additional evidence of, and alternative perspectives on craftsmanship.

(FIGURE 3)

Through handling the punches, feeling their weight and sensing their scale, we were able to get an impression of the punches as working tools. Using RTI, laser scanning and 3-D printing in combination we added to the haptic impressions by successfully capturing hitherto unseen features from the surface of the punches. Using just a single method of observation would not have provided such detail. An initial examination of the sample images revealed lines invisible to the naked eye. Some of these lines are evidence of high usage and show how the edges of the punches were worn away over time. The variations in the marks also reveal 
that multiple hands, with differing levels of skill, produced the punches. This starts to tell us something more about the size of Baskerville's workshop and the numbers of people he employed and their varying levels of capability. The images also reveal aspects of the tempering process and raised questions about the level of skill required by the punch-cutter in order to maintain an even temperature across a differing mass of steel caused by the thick and thin strokes of Baskerville's letters. Finally, the images also demonstrate Baskerville's design in its original and most perfect form: they reveal his true intention for the typeface with all its nuances-some of which become lost in the subsequent stages of manufacture and in the printing where a certain degree of 'spread' occurs. The punches give the authentic relations between the thick and thin strokes and no other available standard can provide this detail with such accuracy. Through laser scanning and RTI imaging we have been able to record the precise dimension, scale-and, therefore, design intent—of the thick and thin stokes of Baskerville's lowercase ' $\mathrm{g}$ '. In combination, these two methodologies have proven to provide an accurate record of the design calibration which provides primary typographical information for further analysis. The punches are, therefore, of great value for the establishment of authenticity: any study of Baskerville's typeface should be controlled by reference to the punches.

The RTI, laser scanning and 3-D printing were highly successful in revealing hitherto unnoticed scratches, dents and surface undulations-tool marks which bear witness to the maker. The next step is to learn to read the punches in order to interpret these marks of manufacture. Identifying patterns in the witness marks will provide some indication of the processes that were applied to the steel in order to create the punch in the first place. Measurements obtained during scanning will also help answer questions regarding scale and ratio, and reveal if Baskerville had developed a formula for their production. Namely, was there a mathematically rendered pattern or was their production dependent on the hand skill of the craftsman? Was there a protocol for creating the punches? If we can decipher the craftsmanship involved, we will begin to understand the manufacturing decisions and workshop practices.

\section{Method 4: X-Ray Fluorescence}

Until the start of this project, there has been no attempt to apply material analysis techniques to the collection. The main reason for this is: firstly, the large 
number of punches make it a time-consuming and expensive process; secondly, as historical artefacts they need to be protected from possible damage caused by destructive analysis; and thirdly, they may not be removed from the Library for study. We were very grateful, therefore, that ULC and CUP afforded us the rare opportunity to borrow a small selection of the punches and take them away for analysis to Birmingham Assay Office. The arrival of the punches in Birmingham was, itself an historic moment: a homecoming (albeit temporary), for the punches had been away from their place of origin for nearly 250 years.

Using specialist equipment at the Assay Office, X-Ray Fluorescence (XRF) was used in order to see whether it was possible to ascertain the material composition of the Baskerville punches. ${ }^{48} \mathrm{XRF}$ is a non-destructive analytical technique used to determine the elemental composition of materials. XRF Spectroscopy was used on the surface of the punches to 'excite' the atoms in the alloy. The intensity of the energy emitted by the atoms then provided a reading on the percentage of each element in the punches. The XRF produced extremely precise results and accuracy was maintained by continual calibration against extensive reference standards and subsequent adjustment of the reading. It was anticipated that results would provide a material study of the punches to complement the physical and visual analysis.

The XRF methodology successfully obtained readings from the surface of the punches and generated a considerable amount of data. In all the punches, twenty elements were identified as being present in varying degrees: manganese, nickel, chromium, molybdenum, copper, tin, titanium, vanadium, niobium, cobalt, tungsten, arsenic, lead, zirconium, antimony, bismuth, tellurium, zinc, cadmium, and iron. As the punches are made from steel the greatest element was, predictably, iron. However, it was the trace elements, which are less than $1 \%$, that were the most intriguing. From these it will be possible to ascertain from where the material originated. If patterns can be identified in the trace elements it will also be possible to 'batch' the punches to confirm which were made together in the same place and at the same time. It will also allow a comparative analysis which will confirm those made in Birmingham and those produced in France and whether there was any difference in the composition and quality of the steel used in the two locations. Although a larger quantity of

48 P. Storme, E. Fransem, K. de Wael, J. Caen, 'X-ray fluorescence as an analytical tool for studying the copper matrices in the collection of the Museum of Plantin-Moretus' TIJD Schrift voor boek wetenschap, Jaarg 95, 2017.1, pp. 7-33. 
punches needs to be scanned before any firm conclusions can be drawn, the pilot project has confirmed that XRF can be a useful tool for determining groups in the study of these historical steel punches.

\section{Method 5: Conspectus}

However, before work can progress it is important to understand the composition of the collection. To do this an enumerative, descriptive and visual conspectus of each punch will be created which will: firstly, create a list each punch required to produced Baskerville's type; secondly, enumerate the surviving punches-size, character, fount-which will be cross-checked with extant archival documentation; thirdly, describe the physical characteristics of the individual punches-weight, dimension; fourthly, survey the condition of each punch-quality, imperfections, breaks, wear-and-tear; and finally, take a 'passport' photograph of each punch. The conspectus will provide a written and visual description of the punches against which the material data can be plotted.

\section{Conclusion}

Typographic punch-cutting is an all-but-lost skill. Over the centuries, it was replaced firstly by mechanical methods, then film and photocomposition and latterly digital techniques. Baskerville punches are the 'masters' from which all his roman type was produced as such these rare survivors: in the absence of examples of his matrices or type, they are of primary importance. The aim of the pilot project was to develop a methodology which would enable an analysis of the punches in order to gain an enhanced understanding of eighteenth-century punch-cutting techniques in general and Baskerville's methods of casting type from matrices struck from engraved punches, in particular.

The pilot project certainly proved the efficacy of using five different methodologies-RTI, laser scanning, 3-D printing, XRF, and a conspectus-in tandem. Perhaps the most exciting aspect of the methodology was discovering the potential for what can be achieved by translating the punches from analogue to digital and back again, in order to show something which cannot otherwise be seen. The inclusion in the project of cross-institutional and multi-disciplinary researchers enabled the amalgamation of established research processes, such as bibliographical and historical methodologies, with traditional crafts techniques which could then be married with twenty-first century technology. 
Now that the methodology has been tested and validated, the next step is to undertake a more extensive examination of the Baskerville punches in order to produce sufficient data from which meaningful results can be extracted. A detailed visual, physical and material analysis of the punches is required and will necessitate craftsmen, technicians, metallurgists and typographic historians to work in tandem to interpret the results. In doing so, it is anticipated that we will be able to deconstruct how the punches were made and therefore provide valuable insights into the skills and technical abilities of eighteenth-century artisans, as well as shedding light on their understanding of the properties and behaviours of metal. It will also extend our knowledge of Baskerville beyond his books, and add to the historical narrative of Baskerville, the man and the typeface. In addition, by refining the methodology still further, it can be replicated across a whole range of typographical material, improve our understanding of other eighteenth-century techniques and add to the wider discourse of printing history. 